Western University

Scholarship@Western

Aboriginal Policy Research Consortium International (APRCi)

2005

\title{
Aboriginal Pastoralism, Social Embeddedness, and Cultural Continuity in Central Australia
}

Nicholas Gill

University of Wollongong

Follow this and additional works at: https://ir.lib.uwo.ca/aprci

Part of the Place and Environment Commons, and the Sociology of Culture Commons

Citation of this paper:

Gill, Nicholas, "Aboriginal Pastoralism, Social Embeddedness, and Cultural Continuity in Central Australia" (2005). Aboriginal Policy Research Consortium International (APRCi). 429.

https://ir.lib.uwo.ca/aprci/429 
This article was downloaded by: [University of Western Ontario]

On: 09 December 2012, At: 07:37

Publisher: Routledge

Informa Ltd Registered in England and Wales Registered Number: 1072954 Registered

office: Mortimer House, 37-41 Mortimer Street, London W1T 3J H, UK

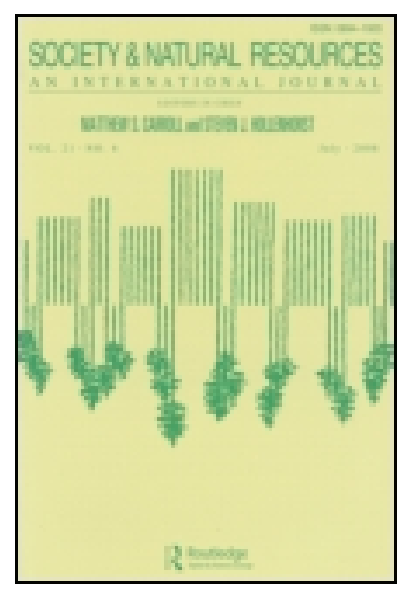

\title{
Society \& Natural Resources: An International J ournal
}

Publication details, including instructions for authors and subscription information:

http:// www. tandfonline.com/loi/ usnr20

\section{Aboriginal Pastoralism, Social Embeddedness, and Cultural Continuity in Central Australia}

\author{
Nicholas Gill ${ }^{\text {a }}$ \\ ${ }^{a}$ GeoQueST Research Centre, School of Earth and Environmental \\ Sciences, University of Wollongong, Wollongong, New South Wales, \\ Australia \\ Version of record first published: 01 Sep 2006.
}

To cite this article: Nicholas Gill (2005): Aboriginal Pastoralism, Social Embeddedness, and Cultural Continuity in Central Australia, Society \& Natural Resources: An International J ournal, 18:8, 699-714

To link to this article: http:// dx.doi.org/ 10.1080/08941920591005089

\section{PLEASE SCROLL DOWN FOR ARTICLE}

Full terms and conditions of use: http://www.tandfonline.com/page/terms-and-conditions

This article may be used for research, teaching, and private study purposes. Any substantial or systematic reproduction, redistribution, reselling, loan, sub-licensing, systematic supply, or distribution in any form to anyone is expressly forbidden.

The publisher does not give any warranty express or implied or make any representation that the contents will be complete or accurate or up to date. The accuracy of any instructions, formulae, and drug doses should be independently verified with primary sources. The publisher shall not be liable for any loss, actions, claims, proceedings, demand, or costs or damages whatsoever or howsoever caused arising directly or indirectly in connection with or arising out of the use of this material. 


\title{
Aboriginal Pastoralism, Social Embeddedness, and Cultural Continuity in Central Australia
}

\author{
NICHOLAS GILL \\ GeoQueST Research Centre, School of Earth and Environmental Sciences, \\ University of Wollongong, Wollongong, New South Wales, Australia
}

\begin{abstract}
Aboriginal people are involved in pastoral enterprises throughout the inland and north of Australia. This has generated difficulties as landowners and policymakers struggled with conflicts between Aboriginal social structures and the demands of running commercial businesses. Problems often arose due to imposition of nonindigenous norms regarding land use. It has been suggested that pastoralism can generate social and cultural benefits for Aboriginal landowners, but these have not been investigated in any detail. Drawing on the concept of social embeddedness and fieldwork with Aboriginal pastoralists, this article identifies, describes, and ranks sociocultural benefits arising from Aboriginal pastoralism. Pastoralism fulfilled uniquely Aboriginal aims and was most important for its role in Aboriginal social and cultural and reproduction. In the Aboriginal context, pastoralism should be conceived in terms that include these Aboriginal motivations and that recognize the social embeddedness of pastoralism.
\end{abstract}

Keywords cultural benefits, embeddedness, indigenous landuse, land rights, Northern Territory, pastoralism, ranching, social benefits

Since the 1970s, Aboriginal people in Australia have regained ownership of significant areas of land in the inland and north of Australia. In some regions much of this land has historically been used for extensive pastoralism (ranching). Nationally, Aboriginal people have acquired about 100 pastoral properties in the last three decades (Phillpot 2001). In the southern Northern Territory (NT), 20\% of former or current pastoral properties were Aboriginal owned by 1997. Although the priority of Aboriginal people in obtaining legal ownership of traditional lands has been maintenance of Aboriginal society and culture, commercial pastoral businesses have been established on many areas of Aboriginal land (Figure 1). For reasons detailed later in this article, many of these enterprises have not succeeded in conventional non-Aboriginal and commercial terms.

Received 22 June 2004; accepted 9 March 2005.

This research was only possible with the assistance and contributions of M. Japanangka Kennedy, Paul Mitchell, Kay Anderson, Richard Baker, Deborah Bird Rose, Richard Davis, Michael Adams, George Curry, and Lesley Head. Land and Water Australia and the Tropical Savannas CRC supported this research. Colgate University in New York provided a home during study leave.

Address correspondence to Nicholas Gill, GeoQueST Research Centre, School of Earth and Environmental Sciences, University of Wollongong, Wollongong, NSW 2522, Australia. E-mail: nicholas_gill@uow.edu.au 


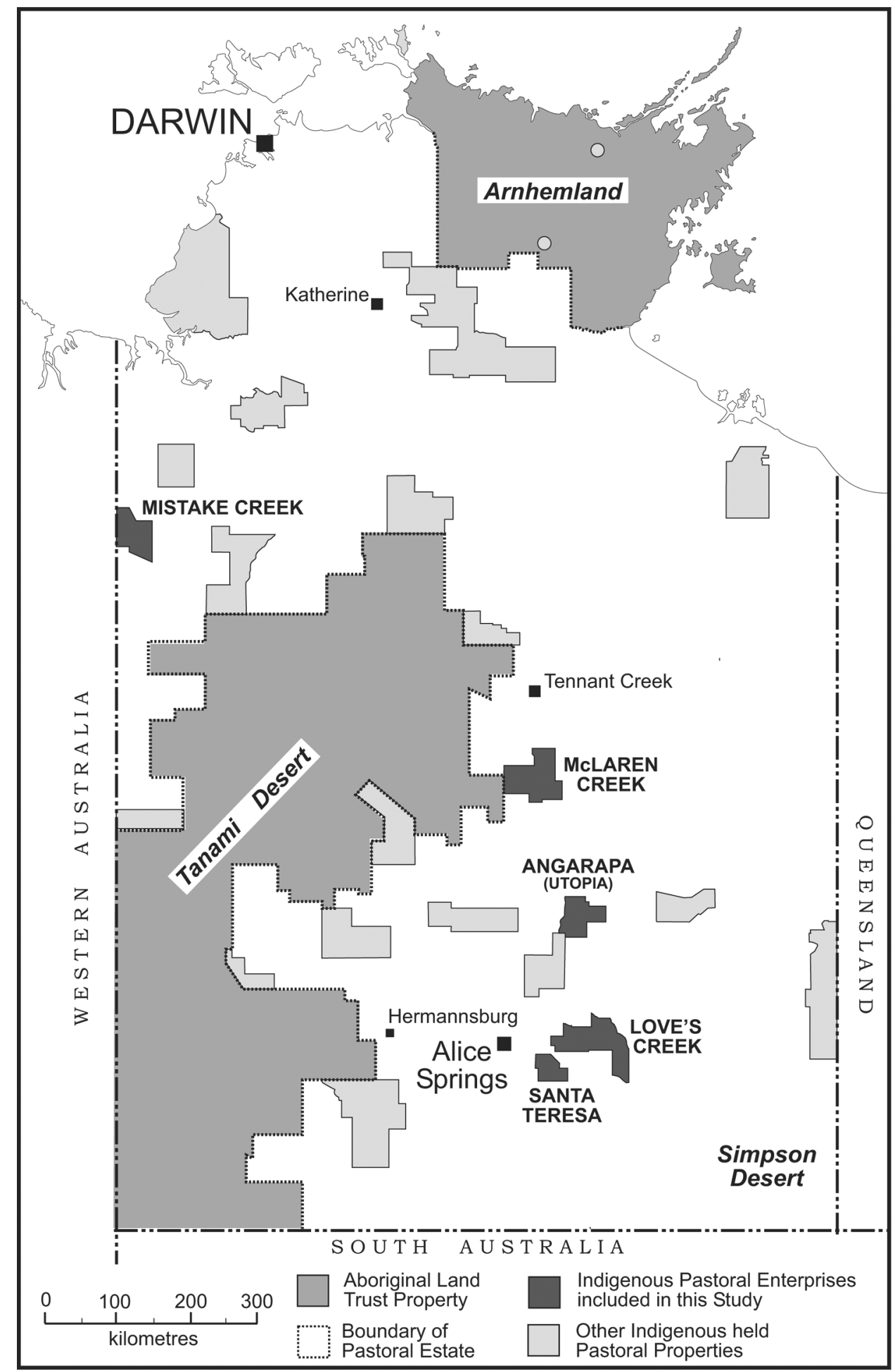

Figure 1. Aboriginal land and pastoral properties in the Northern Territory. After Northern Territory Department of Lands Planning and Environment (1997) and fieldwork. 
The failure of Aboriginal rural enterprises often results from conflicts between Aboriginal land ownership priorities and expectations, on the one hand, and the assumptions and behavior of non-Aboriginal funding agencies and managers on the other. Moreover, researchers and others have argued that Aboriginal people often desire rural enterprises for social and cultural benefits as much as for economic benefits. These social and cultural benefits are, however, rarely clearly articulated beyond reference to employment. Moreover, they tend to be separated from economic aspects of enterprises without explicit attention to the interrelationships between the economic and the social in Aboriginal pastoral enterprises. In this article, drawing on the idea that the economic is always socially embedded, I address these gaps in research concerning Aboriginal pastoralism. Based on a study of Aboriginal pastoralists in the Northern Territory (Figure 1), this article finds that the meaning of pastoralism, with its role and benefits, among Aboriginal landowners cannot be simply inferred from conventional non-Aboriginal understandings of this land use. It is not simply a matter of making hard distinctions between economic/ commercial land uses and social/cultural land uses. Consistent with dominant conceptions of the economy in solely market and capitalist terms, pastoralism is largely interpreted as a market-oriented activity, yielding a commercial surplus and providing paid employment. This article challenges this limited interpretation of pastoralism in the Aboriginal context and provides evidence of Aboriginal priorities for running pastoral enterprises. First, the article briefly outlines background elements of Aboriginal pastoralism. It then discusses the cultural politics of land in the NT and draws on the concept of social embeddedness to critically assess political and policy approaches to Aboriginal pastoralism. Following the methods used in this study, the results are presented in several sections. First, Aboriginal motivations for running enterprises are outlined and ranked. Second, the priority of running pastoral enterprises for cultural benefits is shown to be associated with the processes by which cultural reproduction occurs in Aboriginal societies. Third, Aboriginal pastoralism is linked to Aboriginal concerns about the certainty of their title to land and the possibility that the nature of non-Aboriginal society remains opaque to Aboriginal people. The article concludes by assessing the relevance of social embeddedness to interpreting Aboriginal pastoralism.

\section{Aboriginal Land Ownership and the Cultural Politics of Land in the Northern Territory}

Aboriginal land ownership in Australia is concentrated in the NT, and in the inland and north in general. For Australia in total, up to $18 \%$ of the land area is under Aboriginal ownership, and within the NT, over $40 \%$ of the land area is under Aboriginal ownership (Pollack 2001). Some of the land now owned by Aboriginal people is former pastoral lease land, or is still pastoral leasehold land but is now Aboriginalowned and under land claim for conversion to Aboriginal freehold under the Aboriginal Land Rights (NT) Act (1976).

Aboriginal pastoralism has been a prominent Aboriginal land use and economic development issue in the extensive pastoral lands of inland and northern Australia. Historically, Aboriginal people in the NT were incorporated into the pastoral industry in such a way that they could often maintain contact with their land. Aboriginal stockworkers gained status from their skills, and many developed a strong identification with the cattle industry. For many men and women, such associations were 
born of past employment in the industry and continue to be part of their identity and persona (Baker 1999; McGrath 1987). This history contributes to the desire of some Aboriginal landowners to run pastoral enterprises.

Phillpot (2000) distinguishes between several different types of Aboriginal pastoral enterprises. These range from fully commercial, nonsubsidized businesses through to noncommercial, subsistence-oriented operations. They should be seen as lying on a spectrum, rather than as discrete types. For instance, noncommercial operations may at times sell cattle on the open market. Furthermore, such enterprises can move between categories as circumstances change. The reasons proffered for enterprise "failures" by researchers examining the relationship between Aboriginal society and commercial businesses are diverse and well known (e.g., see Dale 1992; Phillpot 2001; Thiele 1982; Young 1988a). They include factors common to all inland and northern Australian pastoral enterprises and factors arising from Aboriginal values (see especially Young 1988b). For example, many pastoral enterprises in the inland and north are in areas of highly variable rainfall, and long periods without effective rainfall are common. Another key issue has been pitfalls associated with the need to meet the requirements of Australian corporate law and those related to Aboriginal social and landowning structures. Many of these problems are related to conflicts stemming from the fact that Aboriginal people have primarily sought legal ownership of traditional land in order to reassert Aboriginal relationships to land.

While there have been Aboriginal pastoral enterprises that have succeeded commercially and provided paid employment for Aboriginal people, there have been a number that have failed in commercial and "whitefella" terms. Critics of Aboriginal land ownership point to such failures as confirmation of the wastefulness of Aboriginal land ownership and of the need for pastoral land to remain oriented toward the production of a commercial surplus. For example, a clear statement of position came from the NT Chief Minister in 1994 when he said, "I have no objections to Aboriginal ownership of pastoral properties if they are productive and managed properly... But the fact is that many properties taken over by Aborigines have gone backwards for want of investment and expertise" (NT Chief Minister, Northern Australian Cattlemen's Association Conference 8/4/1994).

Such a statement passes for common sense in the dominant "whitefella" culture of the NT. Yet this view contains assumptions that show it to be a peculiarly "whitefella" view of pastoralism, which assumes the primacy of land and pastoralism conceived in terms of formal employment and production of commodities for the market for the benefit of landowners, the region, and the nation. Australian policy for the purchase of land on behalf of Aboriginal people and subsequent funding for pastoral enterprises have been largely driven by such thinking until recently. This has generated a range of difficulties for Aboriginal landowners and pastoral enterprises since the 1970s.

More recently, the Indigenous Land Corporation (ILC), a federal statutory body created to purchase land on behalf of Aboriginal people and to provide Aboriginal landowners with assistance with land management, has articulated a policy position that similarly demarcates the economic realm from the social or cultural. While the ILC prioritizes cultural and social benefits of land purchase, it distinguishes these from economic outcomes and runs different land acquisition programs to address needs defined as either cultural and social, economic, or environmental (Indigenous Land Corporation 2002). For many regions with large Aboriginal 
populations, however, such strong distinctions obscure the nature of Aboriginal economic activity across market and nonmarket arenas (Altman 2001). In distinctions between the economic and the social inheres an inability to discern the reality of hybrid Aboriginal economies and the mutual constitution of cultural, social, and economic realms.

The concepts of economic hybridity (Yang 2000) and social embeddedness (Curry 2003) have provided means of understanding economic formations in indigenous, transitional, or traditional cultural settings. These perspectives begin from the argument that economic formations around the world contain both capitalist and noncapitalist forms (Gibson-Graham 1996). Interpreting economies solely in capitalist or market terms is to miss the significance of diverse noncapitalist logics that inform what people do. Similarly, in the indigenous context, interpreting economic activity solely in light of premodern logics may be result in an incomplete account. As Yang (2000) and Curry (2003) note, indigenous economies are not displaced or removed by capitalism, but are able to renew and refashion themselves in light of new opportunities, producing economic forms constituted by a diverse range of both market and place-based nonmarket logics. In this context, interpreting an activity such as Aboriginal pastoralism requires uncovering those nonmarket economic logics.

The concept of social embeddedness is useful for interpreting the role, operation, and function of apparently market-oriented activities in indigenous settings (Curry 1999; 2003). In general, embeddedness refers to the "contingent nature of economic activity with respect to cognition, culture, social structure and political institutions" (Zukin and DiMaggio 1990, 15). This notion is derived from the work of Polanyi (1957), who argued that there is not and could not be an autonomous economic sphere divorced from social settings (Block 2001; Zukin and DiMaggio 1990). The way in which an "economy is constituted depends on the way it is embedded in society [and] different forms of social embeddedness will give rise to different types of economies" (Curry 2003, 409).

A further key point is the embeddedness of any economic activity or transactions within a range of motivating logics on the part of participants and within a wide range of social relationships and interpersonal relationships (Curry 2003; Zukin and DiMaggio 1990). For example, in Papua New Guinea, Curry (1999) has shown that trade stores, while superficially market-oriented businesses, bear little resemblance to market enterprises in their purpose and operations. More important is their role in demonstrating prestige and in the maintenance of kinship networks; the establishment and operation of the stores are "imbued with place-based values and meanings that are premodern and premarket in form" (Curry 2003, 411). These forms of economic activity confound the dualism of market-oriented activities, the autonomous economy, versus those activities belonging to sociocultural nonmarket realms. Instead, activities such as the trade stores and, it is argued here, Aboriginal pastoralism are an "alternative modernity" (Curry 2003, 410). In the case of Aboriginal pastoralism, this requires that Aboriginal pastoralism not be interpreted solely as a market-oriented activity or as an activity motivated by yearnings for the "old ways," be they those of tradition or those of a golden era of Aboriginal employment in the pastoral industry. The issue is not that of a divide between modernity and premodernity or nostalgia, but is to be attentive to the range of logics underpinning contemporary Aboriginal pastoralism and to the implications of this for the future management of Aboriginal pastoralism. 


\section{Methods}

The fieldwork on which this article is based took place over a 2-year period as part of a broader study of pastoralism in Central Australia (Gill 2000). Each of the Aboriginal pastoral enterprises are located within the area serviced by the Central Land Council (CLC), a key Aboriginal organization in the region. The CLC's Rural Unit facilitated introductions to Aboriginal pastoralists. The project was discussed with the individuals and cattle company directors concerned and if they expressed willingness to participate, these initial visits were followed up with at least one research visit. In 1997, the CLC estimated that there were around 18 Aboriginal pastoral operations in total in the Alice Springs district (P. Mitchell, CLC, personal communication 11/11/97), and individuals involved in five of these pastoral enterprises were interviewed for this study (Figure 1). In total, 33 individuals were involved in the research. Three of these pastoral enterprises were noncommercial operations at the time of fieldwork, although two of them had formerly operated on a commercial basis. These noncommercial operations are all located in the southern NT. The fourth enterprise is a commercial operation in the Victoria River District in the northwest of the NT. A further commercial operation is located in the southern NT.

Various methods were used to discuss, identify, categorize, and rank the benefits of pastoralism. In particular, the study was conducted using participatory approaches developed for research in settings where social and cultural factors mean that conventional quantitative research methods are inappropriate but where some form of quantitative categorization and output are desirable (Maxwell and Bart 1995; Waters-Bayer and Bayer 1995). The precise nature of the methods used varied to some extent between the pastoral operations. This was due to various factors, which included opportunities for participation in enterprise activities, the extent to which Aboriginal pastoralists were willing to be involved in the study, and the nature of the relationships that developed between the author and the Aboriginal participants. For example, Aboriginal pastoralists at two of the noncommercial enterprises were particularly willing to participate in the study and also allowed participation in activities such as building cattle yards. As a result, there is richer ethnographic material relating to these enterprises than to the other enterprises included in this study. This is reflected in the sections that follow. Nonetheless, interviews and informal discussions at all enterprises were informed by a consistently applied set of questions and issues. In addition to this, participation in activities such as yard building and traveling to relevant sites such as rockholes, yards, and other places of cattle work facilitated further informal discussions regarding pastoral enterprises.

The final method was an exercise in ranking the benefits of pastoralism. Twentytwo Aboriginal pastoralists participated in this stage. This ranking exercise was undertaken in the latter stages of fieldwork. The three general categories of benefits were identified through the previous interviews and fieldwork with Aboriginal pastoralists. The first benefit, "keeping culture/(young) people strong," refers to the idea that through pastoralism Aboriginal culture can be maintained and the people kept healthy and on country. The second benefit, "money," refers to the generation of direct economic benefits to landowners, such as director's fees, employment, or funds for community resources. The third benefit, "killers," refers to the provision of fresh beef by the pastoral enterprise to the Aboriginal landowners. "Killer" is the term used in the inland and north to describe a cattle kept or slaughtered to provide meat for consumption, not sale. This was articulated as a separate benefit 
during previous fieldwork and so was kept distinct from "money." The validity of these categories was discussed with Aboriginal pastoralists to confirm their consistency with their views of the potential benefits of cattle enterprises. Twenty-two Aboriginal pastoralists then participated in ranking the three benefits. The benefits were represented pictorially, and participants were asked to allocate 10 tokens among the three benefits to express their view of the relative importance of the benefits (Maxwell and Bart 1995). The results of this ranking are presented in Table 1. This article is based on these ranking results and the insights generated from the preceding ethnographic fieldwork.

\section{Looking After Cattle, Looking After Country}

\section{Priorities}

For the Aboriginal pastoralists in this study, pastoralism is secondary to the imperatives of regaining and controlling country and fulfilling one's obligations to country and kin. As shown in Table 1, for both commercial and noncommercial enterprises, Aboriginal pastoralists in this study ranked the cultural and social benefits of pastoralism above other perceived benefits. Specifically, they see pastoralism having a role in the maintenance of Aboriginal culture. Although women in the commercial enterprises ranked economic benefits above such cultural benefits (possibly due to the role of men in educating younger men in Aboriginal law and culture; see later discussion), economic benefits in the form of money for wages or projects were generally ranked lower than cultural benefits. Women also ranked the supply of fresh beef higher than men, who ranked cultural benefits most highly. Most Aboriginal pastoralists perceived money as important only insofar as it enabled the pastoral enterprises to continue. This can include payment of wages, and commercial Aboriginal pastoral enterprises in Central Australia have been able to provide at least seasonal paid work to landowners. Having the enterprise and maintaining it, however, was seen as a desirable outcome in itself. For example, a study at Central Mt. Wedge into the feasibility of a cattle enterprise found the Aboriginal landowners were indifferent as to whether they had 5000 or 100 cattle; what mattered to them was having a cattle station (P. Mitchell, Central Land Council, personal communication 15/11/97). In the schema presented here, some caution as to separating out monetary benefits from others must be exercised. To the extent that landowners may receive direct cash payments - for example, sitting fees if they are pastoral company directors - such funds are likely to be redistributed among kinship networks or via card games. In this sense, these monetary benefits are always locally socially embedded.

\section{Holding Country}

Aboriginal pastoralism, however, should not be seen as something simply incidental to the maintenance of culture. The Aboriginal pastoralists also saw pastoralism as a means by which to maintain Aboriginal culture. It was this view from which the category "Keeping culture/(young) people strong" emerged. While past studies of Aboriginal involvement in pastoralism point out that Aboriginal people carry out pastoralism for primarily social reasons, the studies generally do not elaborate as to the nature of these reasons. Some historical research does provide some relevant insights (Baker 1999; McGrath 1987); however, its findings in relation to the links 


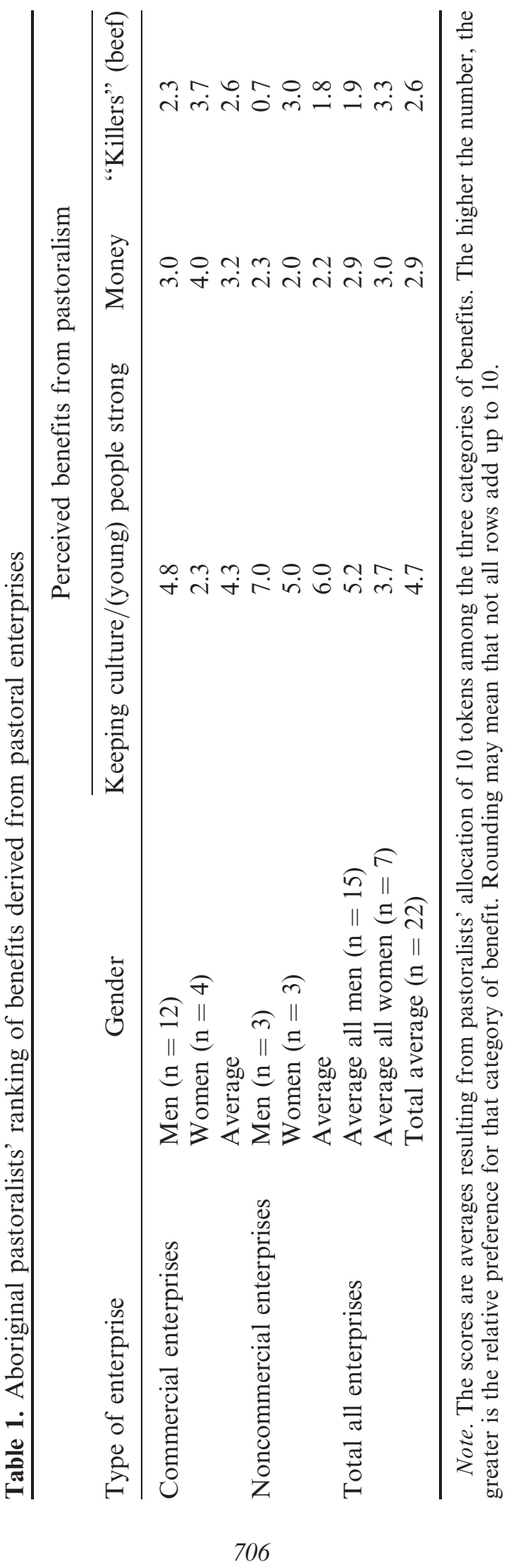


between cattle and Aboriginal cultures have not significantly entered assessments of the role of contemporary Aboriginal pastoralism to date.

This section illustrates some ways in which Aboriginal pastoralists interviewed for this study see pastoralism as a means of ensuring Aboriginal cultural continuity. The starting point for this discussion is the Aboriginal concept of "country" as a part of a matrix of people, society, land, their interrelationships, reciprocities, and moral order. Country, with the relationships it embodies, is fundamental to Aboriginal society and social organization. Aboriginal identity is derived from country, and a person has rights and responsibilities to country that must be fulfilled.

"Country" and Aboriginal social organization are themselves founded on the "Dreaming." The "Dreaming" is simultaneously the ontology, beliefs, stories, and logic that, in Aboriginal culture, constitute the cosmos, the land and society, and provide principles and laws by which to live (Myers 1986; Rose 1992). The Dreaming is both a pasttime in which spirit ancestors created the landscape and the present, in which the actions and presence of these ancestors remain in the land and in people (Myers 1986). One's "Dreaming" links a person with place and "provides the basic source of his or her identity, an identity that pre-exists" (Myers 1986, 50). Such relationships are the basis for Aboriginal land ownership and may be formed through a variety of social relationships such as conception site, birth site, or those of one's parents (Rose 1992).

Customary Aboriginal ownership of country brings responsibilities as well as rights to owners. The relationship with country is reciprocal: "The person takes care of the country and the country takes care of the person" (Rose 1992, 107). In the Aboriginal usage, "looking after" or "caring" for country carries the sense of "holding" a country as one would carry a responsibility, and denotes an active and intimate relationship between the holder and what is held (Myers 1986). Holding a country also implies that one is fulfilling a role that transcends the present and the individual. The individual holds the country until the succeeding generation takes on the responsibility upon their death. The holder is part of a cosmological order in which the individuals play a relatively temporary role. The imperative is to maintain the Law; the Dreaming provides "an order to which all are subordinated" (Myers 1986, 52). The responsibilities of "holders" to country include a range of activities such as using the country by hunting and gathering, protecting the country from damage, providing a new generation of owners educated in Aboriginal law to take over the responsibilities, and learning and performing the ceremonies that keep country and people strong and healthy (Rose 1992, 106-107). A physical presence is required to properly maintain these responsibilities, and regaining land provides opportunities to pursue these obligations more readily.

\section{“Really Proper Way, That Way"-Aboriginal Pastoralism and Cultural Continuity}

The Aboriginal pastoralists whom I interviewed perceive that, despite having gained ownership of land, there remain future uncertainties in meeting obligations to country. Related to this, they worry that they are not fulfilling obligations to the young people whom they "hold" in a similar way to country, and to whom they have obligations to "look after" and "grow up." Concerns for young Aboriginal people and about the future of country are part of the desire to run cattle enterprises.

Nostalgia for the past and concern for youth are not confined to Aboriginal society. Yet the concerns of Aboriginal pastoralists about their young people are real 
and, as a factor in the desire to run pastoral enterprises, influence the use of land and financial resources. As the interviews showed, the concerns of older Aboriginal pastoralists (aged from their fifties) are also rooted in severe physical and mental health problems faced by many Aboriginal people in Central Australia and elsewhere. In particular, these people were concerned about young people leaving their homes and the potential for excessive alcohol consumption and death and injury from violence or trauma such as car accidents. These are all contributors to disproportionately high Aboriginal mortality, morbidity, and injury rates in the NT and Australia as a whole (Territory Health Services 1998; Trewin and Madden 2003). Alcohol consumption is illegal on much Aboriginal land, and the attractions of town, including alcohol, can draw young (and older) Aboriginal people away from their home country (Wright 1997).

This potential for violence and loss clearly concerned the Aboriginal pastoralists who participated in this study. A Warumugu man from near Tennant Creek, bearing responsibilities for both country and a number of younger people, expressed his concern about young people leaving their country, and getting involved in violence in town:

Some of them people... run away all the time... son running away ... only father and mother back [home]. That's where some people disappear, some people rip,'em with a knife, it'll be dead people. (Warumungu pastoralist)

Aranda and Alyawarra Aboriginal pastoralists further south expressed similar fears in relation to violence, knife fights, and car accidents.

The Aboriginal pastoralists were looking for ways to keep young people, especially the young men, on the country. They perceived there was little for the young people to do when at outstations or in settlements, and sought to find activities that would interest them and stop them getting "wild" and "on the grog" (Aranda Aboriginal pastoralist). This view of life on outstations was confirmed by several of the young men (aged 18-22) interviewed at one enterprise, who said they found life a little "boring" at the outstation, several hundred kilometers from Alice Springs.

The problem of young people going into town and getting "on the grog" is not only related to concern about their well-being and about fulfilling responsibilities to "look after" them. As outlined earlier, in order to fulfill their obligations to country, owners of country have responsibility for providing a new generation of knowledgeable owners to succeed them. That they are unable to ensure the presence of young people on country was therefore a source of concern to the Aboriginal pastoralists interviewed. The possibility that the young people would not learn from them in time caused them to worry that they would fail to "hold" the country:

"You fellas got to take him on this one now. We pass away, you got to understand". We bin tell "em [the young men] that... We got to give' em our culture. You know. We can't lose this culture, otherwise we'll lose it ... we gotta keep going this way, the blackfella law, he can't change, that ceremony law he can't change. It's still longa [with] that old law, from early days... on and on, never change, still longa that law. (Alyawarra pastoralist) 
A Warumungu pastoralist also expressed this fear of "losing" the law and the country if the youngfellas are in town:

They lost the country, he might [sic] lost himself ... he don't know anything about it, no ceremony business, he don't know sacred sites, he lost himself altogether. (Warumungu pastoralist)

In this context "lost" has a particular meaning. Losing can be thought of as "forgetting," and as a significant cultural loss (Arthur 1996). The Pintupi concept of wantininpa, which refers to "losing" or "leaving," and which can apply to people or country, conveys this sense of loss (Myers 1986). Myers (1986), however, indicates that, in relation to country, the concept carries the implication of handing that country on, of losing it on death, but leaving it for the next generation. These men just quoted appear to fear a more serious loss: the loss of the country not only to themselves upon their death but also to their children, who they fear may not equipped to take up responsibility for country. They fear a loss of self and identity for those young men who have "lost" their country. They also fear a loss of knowledge that will not be easily filled, which will lead to the loss of country through the loss of rights to "own" that country in Aboriginal terms.

Rights to country must be maintained by visiting country and sites, learning the stories and rituals, and keeping country and sites "clean." Instruction in these matters by older men is a "crucial component of the social reproduction of ownership and through it the production of adult men" (Myers 1986, 151). An important aspect of owning country is being able to demonstrate this knowledge to others, as holding country also comes from others agreeing to recognize one as a legitimate owner (Myers 1986) - people are "witness for one another" (Warumungu pastoralist). If "youngfellas" are away from their country, away from the elder men, and drinking in town, they are not in a position to learn as they should, and knowledge and ownership of country is seen to have the potential to be "lost."

At all five locations of the Aboriginal pastoral enterprises examined in this study, the Aboriginal pastoralists expressed concerns about keeping young people on country and about alcohol. Cattle work was seen as a means by which young men could be enticed to stay at home and be "on the country" in the company of knowledgeable older men. Although, overall, women ranked the cultural benefits of pastoralism somewhat lower then men (Table 1), they largely agreed that cattle enterprises were "good" in that they potentially occupied the young men. Cattle can, however, potentially conflict with the interest of women. Rose (1995) found that women were concerned about issues such as the impact of cattle on bush foods and expenditure of resources on pastoral enterprises rather than on other community needs.

Why do these Aboriginal pastoralists see a role for pastoralism in helping to ensure cultural continuity? The answer lies in the role cattle work played in their own lives and in "growing them up" and in the ways in which Aboriginal and cattle cultures complemented each other. Both McGrath (1987) and Baker (1999) have observed that the activities of NT cattle work, checking waterholes, checking pastures, mustering cattle, and working in stock camps, doubled as opportunities to learn about country "Aboriginal way" and to fulfill obligations to country.

Such moments of gaining knowledge of country are evident in the recollections of cattle work among Alyawarra and Warumungu pastoralists. When these men 
were working on stations, their work provided them with time on country as they rode over it checking on cattle and waters. Traveling and talking with a Warumungu Aboriginal pastoralist in particular revealed his intricate geography of travel routes, waterholes, and sites in the region that he used for various aspects of his pastoral work. In moving around this country, his "father's country," he was able to gain Aboriginal and pastoral knowledge of it and fulfill customary obligations. As a result, he is now able to demonstrate ownership and he needs to pass this ability on to his sons:

\begin{abstract}
My father's country. So I got to follow that. And all our sons ... People getting old and old. He's the one that got to come along, second, to look after country. We used to shift 'em cattle and bring horses. You got fill up your canteen ... good clean water... No bore [well], before. People used to go through with packhorse. And if you want water you got to come down to rockhole. Traditional owner, people belonging to country, well he know all the rockholes ... that where people got to be, that's why [sic] people worrying about — to look after place you know. Keep up with the country so long as young fellas stick to daddy you know. (Warumungu pastoralist)
\end{abstract}

Knowledge of country through cattle work has become a valued "second way" (McGrath 1987) of knowing country, one that sits alongside and can inform the Aboriginal "way." For these older men, cattle work was part of the process, the "proper way" by which Aboriginal customary ownership was reproduced, and by which they were made into men who had the "qualities and discipline associated with adulthood" (McGrath 1987, 167), particularly the ability to meet their responsibilities in Aboriginal law. By instilling in their young men the ability to do cattle work and thereby keeping them on their country they hope to secure the future of people and country by practicing "two ways":

We should cut 'em from them youngfellas [the drinkers]... We got to teach'em all that one... cattle way and business (ceremony) way... so they can understand two way. (Alyawarra pastoralist)

These Aboriginal pastoralists perceive that security of "ownership" comes through mastering both Aboriginal and non-Aboriginal ways. The Aboriginal pastoralists acknowledge that they need some ability to operate in a world dominated by non-Aboriginal values and laws. They see pastoralism as a means by which this can be achieved and as an activity that can be assist in reproducing Aboriginal ritual life and land ownership.

\title{
"Mutual Intelligibility" and Aboriginal Pastoralism
}

A final point illustrates a further way in which these Aboriginal pastoralists, in particular those at two of the noncommercial enterprises, see pastoral enterprises as away of holding onto land. After spending much of their lives without legal ownership of their land, these people have finally regained what they see as theirs. From their perspective a change in government and a change in law caused land to be returned to them. They referred to a time when "everything bin change" or, as elsewhere in the 
NT, to "Whitlam times," in reference to Gough Whitlam, the former Labour Prime Minister who played an important role in the land rights movement in the 1970s (Baker 1999). In contrast to Aboriginal law, which they see as unchanging, "whitefella" laws such as those that have bestowed land ownership on these Aboriginal pastoralists are seen as fickle. In their discussion of the enduring nature of Aboriginal law, the Alyawarra pastoralists contrasted it to non-Aboriginal law:

And this other law, this one here we doing him, cattle business. But... new government come in, he's got different idea and he tell that mob he got to follow that new government law. He's got to change every year. (Alyawarra pastoralist)

Given this perceived instability in non-Aboriginal law, they envisage their land being taken away just as it was given. They saw this as a real threat and interpreted low cattle prices as government revenge on Aboriginal people for gaining ownership of "too many" pastoral leases.

These Aboriginal pastoralists saw pastoralism as a means of gaining recognition of their version of land "ownership" under non-Aboriginal systems of land ownership. In this view, pastoralism is a means of establishing a reciprocal relationship with government in which they are fulfilling their side of a bargain by using and knowing land properly in ways that satisfy non-Aboriginal norms. In the eyes of these Aboriginal pastoralists, amid momentous social changes, pastoralism has been a constant in Central Australia; it has been one aspect of non-Aboriginal life that has persisted more or less as it has been for decades. It seems likely that from this, following the Alyawarra man just quoted, they take pastoralism to be a way of following non-Aboriginal law and fulfilling what are, to them, its somewhat ambiguous and opaque requirements, in the same way that they fulfill Aboriginal law. In this way they hope to retain the right to hold their country under non-Aboriginal law, whether it is Aboriginal or non-Aboriginal law, that is determining ownership in legal terms.

This is perhaps a contemporary example of the lack of "mutual intelligibility," which Rowse (1998) describes as a characteristic of the rationing relationships between Aboriginal and non-Aboriginal people in the past. The confusion arose here, as there was no mutual frame of reference with which to interpret the exchange of goods between rationed Aborigines and settlers up to the late 1960s. Therefore, there was no way of reaching shared interpretations of what should follow. The processes in the non-Aboriginal domain that led to them regaining their land are not clear to these Aboriginal pastoralists. Such social and political processes are shrouded in mystery to them, and they therefore interpret the return of land through Aboriginal concepts (Phillpot 2001).

They now perceived that because the government had given them land and cattle, they needed to keep running cattle to retain the land:

Government bin given us the cattle and the country-same time. We got to worry for cattle. We got to worry for country. Because government bin give it. (Warumungu pastoralist)

Because of this sense of reciprocity, these Aboriginal pastoralists worried about the young men not knowing how to do cattle work and thus losing land: 
If they can't do anything government will pull 'em off. You know that's government law. People not doing right job, they take everything away. (Alyawarra pastoralist)

Keeping the young men interested in, and doing, cattle work is part of a strategy to maintain the presence of cattle and maintain land ownership, and meet obligations arising from both Aboriginal and non-Aboriginal domains.

\section{Conclusion}

Pastoral projects on Aboriginal land have frequently been driven by nonindigenous land use norms and pastoral projects have been funded and managed accordingly. In addition, Aboriginal people have been criticized for not using land "productively." The Aboriginal pastoralists in this study, however, predominantly perceived that pastoralism had social and cultural significance as well as economic outcomes. Further, the significance of their social valuations of pastoralism show that in the Aboriginal context, pastoralism can take on a flexible range of meanings. These meanings disconnect pastoralism not only from its common associations with Australian outback mythology but also from notions of progress, primary production, the national interest, and market activity. Instead, pastoralism can be seen as socially embedded in Aboriginal life, related to localized concerns and based in cultural traditions that long predate the arrival of pastoralism in the Northern Territory. For the Aboriginal pastoralists in this study, being a pastoralist does not mean that they have accepted non-Aboriginal land use norms to the detriment of Aboriginal social and cultural priorities. On the contrary, pastoralism is a means through which these Aboriginal pastoralists hope to reproduce Aboriginal society and retain Aboriginal ownership of land. These Aboriginal pastoralists seek to use pastoralism to create the conditions for their cultural survival using the very tools by which they might be taken to have become "more like whitefellas." Aboriginal pastoralism represents an alternative modernity in which the familiar forms of settler modernity remain present but are turned to countermodern purposes as Aboriginal people continue to search for ways to survive in settler society. The return of land alone has not provided certainty to these Aboriginal pastoralists.

Pastoralism can be "productive" in the sense of fulfilling land use norms that lie outside the non-Aboriginal sense of wise land use, and outside conventional senses of economically profitable rural production. Pastoralism can also be seen as "productive" in an Aboriginal sense. Aboriginal pastoralists, drawing in part on their own working histories and memories, perceive that pastoralism has a significant role in ensuring the continuity of Aboriginal culture and ways of inhabiting country. In this sense, Aboriginal pastoralism demonstrates the difficulties of drawing hard distinctions between economic and other aspects of social life. Pastoralism is socially embedded, and characterizing it as either economic or social is not only unproductive but risks ignoring the very motivations for engaging in pastoral activities and the range of potential benefits that Aboriginal landowners may accrue. This evidence presented here not only illustrates the social and cultural benefits of pastoralism as perceived by Aboriginal pastoralist but also shows that these benefits are highly valued by Aboriginal pastoralism and that they are more highly valued than the strictly monetary outcomes. 
These issues have implications for policy in the area of funding guidelines for Aboriginal land acquisition, enterprises, and management. First, Aboriginal pastoral enterprises that provide a range of benefits for landowners may fall between the cracks of funding programs that run separate economic and cultural programs based on criteria such as commercial viability or "traditional" culture respectively. Such criteria overlook the hybrid or socially embedded nature of Aboriginal pastoral enterprises. Second, the evidence presented here supports the idea that funding of small-scale, noncommercial Aboriginal pastoral enterprises may be justified on social and cultural grounds in that they have the potential to meet noneconomic goals grounded in Aboriginal society. Third, the priorities of Aboriginal pastoralists in this study point to the need for policymakers and funding bodies to thoroughly understand the motivations of Aboriginal people who wish to establish a pastoral enterprise and to not think of such enterprises in conventional economic terms. Any enterprises thus funded would then need to be structured, funded, and managed in such a way as to meet these motivations-for example, to maximize opportunities for travel and work on country. For policymakers and for many Australians, this may be the greatest challenge, to conceive of pastoralism, a pivotal activity in European settlement of Australia, in Aboriginal cultural terms. In running pastoral enterprises for their own cultural purposes, Aboriginal pastoralists continue to confound easy and popular one-dimensional images of both Aboriginal people and the outback pastoral industry that have served non-Aboriginal visions of the inland and north of Australia.

\section{References}

Altman, J. C. 2001. Sustainable development options in aboriginal land: The hybrid economy in the twenty-first century. Discussion Paper 226. Canberra, Australia: Centre for Aboriginal Economic Policy Research, Australian National University.

Arthur, J. M. 1996. Aboriginal English: A cultural study. Melbourne, Australia: Oxford University Press.

Baker, R. 1999. Land is life: From bush to town — the story of the Yanyuwa people. Sydney, Australia: Allen and Unwin.

Block, F. 2001. Karl Polanyi and the writing of the Great Transformation. Paper presented at the Eighth International Karl Polanyi Conference, "Economy and Democracy," Mexico City. http://www.artsandscience.concordia.ca/polanyi/conf/pdf/block.pdf, accessed 1/5/2004.

Curry, G. N. 1999. Markets, social embeddedness and precapitalist societies: The case of village tradestores in Papua New Guinea. Geoforum 30:285-298.

Curry, G. N. 2003. Moving beyond postdevelopment: Facilitating indigenous alternatives for "development." Economic Geography 79(4):405-423.

Dale, A. 1992. Planning for rural development in Aboriginal communities: A communitybased planning approach. In Conservation and development issues in North Australia, eds. I. Moffatt and A. Webb, 200-212. Darwin, Australia: North Australia Research Unit.

Gibson-Graham, J. K. 1996. The end of capitalism (as we knew it). Oxford, UK: Basil Blackwell.

Gill, N. J. 2000. Outback or at home?: Environment, social change and pastoralism in Central Australia. Ph.D thesis, School of Geography and Oceanography, University of NSW, Canberra, Australia.

Indigenous Land Corporation. 2002. Land acquisition and land management programs guide 2002-2006. Adelaide, Australia: Indigenous Land Corporation. 
Maxwell, S., and C. Bart. 1995. Beyond ranking: Exploring relative preferences in P/PRA. Particip. Learning Action Notes 22:28-34.

McGrath, A. 1987. Born in the Cattle: Aborigines in cattle country. Sydney, Australia: Allen and Unwin.

Myers, F. R. 1986. Pintupi country, Pintupi self: Sentiment, place and politics among Western Desert Aborigines. Washington, DC, and Canberra, Australia: Smithsonian Institution Press and Australian Institute of Aboriginal Studies.

Northern Territory Department of Lands Planning and Environment. 1997. Land tenure map - Pastoral and Aboriginal lands. Darwin, Australia: Northern Territory Department of Lands, Planning and Environment.

Phillpot, S. 2000. Black pastoralism: Contemporary aboriginal land use: The experience of aboriginal owned pastoral enterprises in the Northern Territory 1972-1996. PhD thesis, Public Policy Program, Australian National University, Canberra, Australia.

Phillpot, S. 2001. Understanding whitefella secret cattle business. In Working on country: Contemporary indigenous management of Australia's lands and coastal regions, eds. R. Baker, J. Davies, and E. Young, 199-213. Melbourne: Oxford University Press.

Polanyi, K. 1957. The great transformation. Boston: Beacon Press.

Pollack, D. P. 2001. Indigenous land in Australia: A quantitative assessment of outcomes from legislation and programs. Canberra, Australia: Australian National University.

Rose, D. B. 1992. Dingo makes us human: Land and life in an aboriginal Australian culture. Cambridge, UK: Cambridge University Press.

Rose, B. 1995. Land management issues: Attitudes and perceptions amongst Aboriginal people of central Australia. Alice Springs, Australia: Central Land Council.

Rowse, T. 1998. White flour, White power: From rations to citizenship in Central Australia. Melbourne, Australia: Cambridge University Press.

Territory Health Services. 1998. The Aboriginal public health strategy and implementation guide 1997-2002. Darwin, Australia: Territory Health Services.

Thiele, B. 1982. Yugul: An Arnhem land cattle station. Darwin, Australia: North Australian Research Unit.

Trewin, D. and R. Madden. 2003. The health and welfare of Australia's Aboriginal and Torres Strait Islander peoples. Canberra, Australia: Australian Bureau of Statistics and Australian Institute of Health and Welfare.

Waters-Bayer, A. and W. Bayer. 1995. Planning with pastoralists: PRA and more. Eschborn, Germany: Deutsche Gesellschaft fut Technische Zusammenarbeit.

Wright, A. 1997. Grog war. Broome, Australia: Magabala Books.

Yang, M. M. 2000. Putting global capitalism in its place: Economic hybridity, Bataille, and ritual expenditure. Curr. Anthropol. 41(4):477-509.

Young, E. 1988a. Aboriginal cattle stations in the East Kimberley: Communities or enterprises. Canberra, Australia: Centre for Resource and Environmental Studies ANU.

Young, E. 1988b. Aboriginal economic enterprises: Problems and prospects. In North Australia: Progress and prospects, vol. 1; contemporary issues in development, eds. D. Wade-Marshall and P. Loveday, 182-200. Darwin, Australia: North Australian Research Unit.

Zukin, S. and P. DiMaggio. 1990. Introduction. In Structure of capital: The social organisation of society, eds. S. Zukin and P. DiMaggio, 1-36. Cambridge, UK: Cambridge University Press. 